\title{
Analisis Penanganan Pembiayaan Murabahah Non Performing Financing (NPF) Dengan Mitigation Of Risk In Islamic Financial Institutions Di KJKS BMT Al-Makmur Cubadak Lima Kaum
}

\author{
Kab. Tanah Datar
}

\author{
Elmiliyani Wahyuni ${ }^{1}$ \\ Institut Agama Islam Negeri Batusangkar \\ E-Mail: elmiliyaniwahyuni@iainbatusangkar.ac.id / WA 085274452449 \\ Sri Maulidia ${ }^{2}$ \\ CV. Karya Indo Alam Depok \\ E-mail : srimaulidia08@gmail.com
}

\begin{abstract}
The problem in this research is the occurrence of problematic murabahah financing (NPF) over the last three years experienced a significant increase in KJKS BMT Al-Makmur Cubadak Lima Tanah Datar Regency. Therefore, it is necessary to handle problematic financing based on the mitigation of risk. This research uses a qualitative approach to find out how the analysis of handling problematic murabahah financing (NPF) is following the predetermined provisions.The results showed that the causes of problematic financing are lack of analysis in analyzing customer character, weaknesses in coaching and monitoring financing, decreased business income of customers, and customers who deliberately avoid. Furthermore, the analysis of handling problematic murabahah financing (NPF) with the mitigation of risk in KJKS BMT AlMakmur Cubadak Lima Kaum is avoiding and reducing risk. Risk avoidance mitigation is carried out by applying a fine of Rp 1000 for one delay and providing deductions to customers who can pay off the financing before the due date ends. Then the second mitigation is done to reduce the risk by applying financing patterns to ease installment payments of members who have difficulty in paying, with a rescheduling system, in this case, BMT applies the pattern of overtime, and the policy of reducing arrears for the result. But in other respects, BMT does not withdraw guarantees, conversion contracts, and also litigation because the BMT resolves financing problems by way of deliberation.
\end{abstract}

Keywords : Murabahah, NPF, Mitigation of risk

\begin{abstract}
Abstrak
Permasalahan dalam penelitian ini adalah terjadinya pembiayaan murabahah bermasalah (NPF) selama tiga tahun terakhir mengalami kenaikkan yang signifikan pada KJKS BMT Al-Makmur Cubadak Lima Kaum Kabupaten Tanah Datar. Sehingga diperlukan cara penanganan pembiayaan bermasalah berdasarkan mitigation of risk. Penelitian ini menggunakan pendekatan kualitatif untuk mengetahui bagaimana analisis penanganan pembiayaan murabahah bermasalah (NPF) apakah telah sesuai dengan ketetapan yang telah ditentukan. Hasil penelitian menunjukan bahwa penyebab terjadinya pembiayaan bermasalah yaitu kurangnya analisis dalam menganalisa karakter nasabah, kelemahan dalam melakukan pembinaan dan monitoring pembiayaan, penurunan pendapatan usaha nasabah, dan nasabah yang sengaja menghindar. Mitigasi menghindari risiko dilakukan dengan menerapkan denda sebesar Rp 1000 untuk satu kali keterlambatan, dan memberikan potongan tagihan kepada nasabah yang mampu melunasi pembiayaan sebelum waktu jatuh tempo berakhir. Kemudian mitigasi kedua yang dilakukan mengurangi risiko dengan menerapkan pola pembiayaan untuk meringankan angsuran pembayaran anggota yang mengalami kesulitan dalam membayar, dengan sistem rescheduling, dalam hal ini BMT menerapkan pola perpanjangan waktu, dan kebijakan pengurangan tunggakan bagi hasil. Tetapi dalam hal lain BMT tidak melakukan
\end{abstract}


Elmiliyani Wahyuni, Sri Maulidia : AnalisisPenangananPembiayaan...

penarikkan jaminan, konversi akad dan juga litigasi dikarenakan pihak BMT menyelesaiakan permasalahan pembiayaan dengan jalan musyawarah.

Keywords : Murabahah, NPF, Mitigasi of Risk

\section{A. PENDAHULUAN}

BMT merupakan salah satu lembaga ekonomi dan keuangan yang dikenal luas pada masa-masa kejayaan Islam berfungsi sebagai institusi keuangan publik, yang sebagian pengamat ekonomi disejajarkan dengan lembaga yang menjalankan fungsi perekonomian modern. Lembaga keuangan publik ini berhubungan dengan ketentuan, pemeliharaan dan pembayaran dari sumber-sumber yang dibutuhkan untuk memenuhi fungsi-fungsi publik dan pemerintah ${ }^{1}$.

Sebagai lembaga keuangan syariah KJKS BMT Al-Makmur Cubadak berfungsi sebagai penghimpun dan penyaluran dana dari dan kepada masyarakat, dalam penyaluran dana KJKS BMT Al-Makmur Cubadak menerapkan dengan akad murabahah yaitu jual beli barang pada harga asal dengan tambahan keuntungan (bagi hasil) yang disepakati antara kedua belah pihak yaitu penjual dan pembeli ${ }^{2}$. Dalam akad pembiayaan murabahahperhitungan nisbah bagi hasil sangat dipengaruhi oleh tingkat resiko yang mungkin terjadi. Semakin tinggi tingkat resikonya akan semakin besar nisbah bagi hasil dan sebaliknya. Oleh karenanya pengelola BMT harus selektif dalam memilih usaha yang akan dibiayai ${ }^{3}$.

Pembiayaan bermasalah merupakan suatu resiko yang besar yang terjadi di dunia perbankan baik bank umum maupun BMT, kasus pembiayaan bermasalah tidak terjadi secara tiba-tiba, ada banyak faktor yang mempengaruhi terjagdinya pembiayaan bermasalah ialah karakter nasabah, keadaan ekonomi, pengelolaan usaha yang kurang profesional, serta kurang telitinya pihak BMT dalam menganalisis data calonnasabah baik yang disengaja maupun yang tidak disengaja. Pembiayaan bermasalah yang timbul tersebut diperlukan sebuah penanganan agar tidak berkelanjutan menjadi kredit macet. Penanganan pembiayaan bermasalah tersebut haruslah sesuai dengan ketentuanketentuan yang berlaku dalam lembaga keuangan ${ }^{4}$.

\footnotetext{
${ }^{1}$ Muhammad. 2005. Lembaga Ekonomi Syariah

${ }^{2}$ Antonio, Muhmmad Syafi'i. 2001. Bank Syariah: dari Teori dan Praktik

${ }^{3}$ Ridwan, Muhammad. 2004. Manajemen Baitul Maal wa Tamwil (BMT)

${ }^{4}$ Rahmawaty, A. 2007. Ekonomi Syariah Tinjuan Kritis Produk Murabahah dalam Perbankan Syariah di Indonesia
} 
Elmiliyani Wahyuni, Sri Maulidia : Analisis Penanganan Pembiayaan...

BMT Al-Makmur Cubadak Lima Kaum merupakan lembaga keuangan syariah yang tidak terlepas dari suatu masalah pembiayaan macet seperti lembaga keuangan lainnya. Pembiayaan yang mengalami kemacetan pada KJKS BMT Al-Makmur Cubadak Lima Kaum adalah pembiayaan murabahah. Berdasarkan data dari Tahun $2014-2018$ tentang kolektabilitas dan non performing financing (NPF) yang penulis peroleh dari bapak Suhatri Mariko selaku pimpinan KJKS BMT Al-Makmur Cubadak Lima Kaum sebagai berikut:

Tabel 1.1

\section{Data Pembiayaan Bermasalah Pada KJKS BMT Al-Makmur Cubadak} Tahun 2014-2018

\begin{tabular}{|c|c|c|c|c|}
\hline Tahun & $\begin{array}{c}\text { Jumlah } \\
\text { Nasabah }\end{array}$ & $\begin{array}{c}\text { Jumlah } \\
\text { Pembiayaan } \\
\text { (Rp) }\end{array}$ & $\begin{array}{c}\text { Jumlah NPF } \\
\text { (Rp) }\end{array}$ & $\begin{array}{c}\text { Persentase } \\
\text { NPF }\end{array}$ \\
\hline 2014 & 105 orang & 396.157 .500 & 0 & $0 \%$ \\
\hline 2015 & 120 orang & 510.357 .500 & 0 & $0 \%$ \\
\hline 2016 & 125 orang & 399.038 .000 & 26.839 .200 & $6,72 \%$ \\
\hline 2017 & 146 orang & 483.471 .400 & 16.528 .300 & $3,41 \%$ \\
\hline 2018 & 159 orang & 503.558 .844 & 17.312 .000 & $3,43 \%$ \\
\hline
\end{tabular}

Sumber data: Laporan Keuangan KJKS BMT Al-Makmur Cubadak Periode 20142018

Pada tabel 1.1 menjelaskan bahwa hasil dari kolektabilitas pembiayaan dari tahun 2014-2015 pembiayaan bermasalah masih 0, akan tetapi pada tahun 2016-2018 terjadinya fluktuasi pembiayaan bermasalah yang mana di tahun 2016 dengan total NPF Rp 26.839.200 Kemudian mengalami penurunan di tahun 2017 sebesar Rp 16.528.300 dan mengalami kenaikkan lagi sebesar Rp 17.312.000di tahun 2018.

Apabila terjadinya pembiayaan bermasalah maka BMT akan melakukan upaya untuk menangani pembiayaan bermasalah tersebut dengan melakukan upaya penyelamatan dan penyelesaian pembiayaan bermasalah, agar dana yang telah disalurkan oleh BMT dapat diterima kembali. Akan tetapi mengingat dana yang dipergunakan oleh BMT dalam memberikan pembiayaan berasal dari dana masyarakat yang ditempatkan pada BMT, maka BMT dalam pemberian pembiayaan wajib menempuh cara-cara yang tidak merugikan BMT dan kepentingan nasabah yang telah mempercayakan dananya ${ }^{5}$.

\footnotetext{
${ }^{5}$ Kolistiawan, B. 2014. Tinjauan Syariah Tentang Pembiayaan Bermasalah di Perbankan Syariah di Indonesia.
} 
Risiko yang berpotensi timbul pada pembiayaan yang disalurkan BMT disebabkan oleh arus penyaluran pembiayaan yang terus meningkat, maka akan berpotensi pada tingginya tingkat risiko. Untuk itu perlu diterapkan langka mitigasi risiko. Mitigasi risiko itu sendiri bertujuan untuk mengamankan posisi BMT terhadap risiko-risiko yang dapat merugikan BMT dan langkah ini juga merupakan uapaya-upaya dalam meminimalisir terjadinya pembiayaan bermasalah

Selanjutnya Berdasarkan Surat Edaran Bank Indonesia (SEBI) NO.10/34/DPbs tanggal 22 oktober 2008 mengenai restrukturisasi pembiayaan bagi Bank Umum Syariah (BUS) dan Unit Usaha Syariah (UUS) akan melakukan upaya terhadap pembiayaan bermasalah diantaranya: penyelesaian melalui eksekusi jaminan, penyelesaian lewat BASYARNAS, litigasi dan hapus tagih. Sedangkan yang penulis temukan dilapangan tidak adanya tindakan dalam mengeksekusi jaminan dari nasabah pembiayaan macet, tidak adanya penyelesaian melalui pengadilan agama atau BASYARNAS dan tidak adanya tindakkan hapus tagihterhadap nasabah kategori pembiyaan macet. Yang terjadi dilapangan hanya melalui penjadwalan kembali, musyawarah dan perpanjangan waktu bagi nasabah yang memiliki sisa hutang di bawah 50\%, sedangakan laporan kolektabilitas pembiyaan murabahah pada BMT AlMakmur Cubadak Lima Kaum menunjukan peningkatan jumlah pembiayaan macet dan pembiayaan yang; diragukan selama tiga tahun berjalan.

Berdasarkan permasalahan tersebut maka penulis tertarik untuk membahasnya lebih mendalam tentang upaya-upaya yang dilakukan oleh BMT sebagai salah satu lembaga keuangan yang beroperasi dengan prinsip Syariah dalam pelaksanaan atau melakukan tindakan terhadap mitigasi risiko dalam pembiayaan yang disalurkan BMT. Maka dari itu penulis tertarik untuk menuangkannya dalam sebuah karya tulis ilmiah yang berjudul "Analisis Penanganan Pembiayaan Murabahah Non Performing Financing (NPF) dengan Mitigation of Risk in Islamic Finanancial Institutionsdi KJKS BMT Al-Makmur Cubadak Lima Kaum"

\section{B. LANDASAN TEORI}

\section{Pembiayaan Bermasalah}

Menurut Mahmoeddin mengemukakan pengertian pembiayaan bermasalah adalah pembiayaan kurang lancar, dimana nasabahnya tidak memenuhi persyaratan yang telah dituangkan dalam akad, pembiayaan yang tidak menepati jadwal angsuran, sehingga terjadi penunggakan, pembiayaan bermasalah adalah pembiayaan yang tidak 
Elmiliyani Wahyuni, Sri Maulidia : Analisis Penanganan Pembiayaan...

menepati janji pembayaran, sehingga memerlukan tindakan hukum untuk menagihnya, Mahmoeddin juga menyimpulkan bahwa pembiayaan bermasalah adalah pembiayaan yang berpotensi untuk merugikan bank sehingga berpengaruh terhadap kesehatan Bank itu sendiri ${ }^{6}$

\section{Faktor penyebab pembiayaan Bermasalah}

a. Faktor Intern Bank

1) Analisis kurang tepat, sehingga tidak dapat memprediksi apa yang akan terjadi dalam kurun waktu selama jangka waktu kredit. Misalnya, kredit diberikan tidak sesuai dengan kebutuhan, sehingga nasabah tidak mampu membayar angsuran yang melebihi kemampuan.

2) Adanya kolusi antara pejabat bank yang menangani kredit dan nasabah, sehingga bank memutuskan kredit yang tidak seharusnya diberikan.

3) Keterbatasan pengetahuan pejabat bank terhadap jenis usaha debitur, sehingga tidak dapat melakukan analisis dengan tepat dan akurat.

4) Campur tangan terlalu besar dari pihak yang terkait, misalnya komisaris, direktur bank sehingga petugas tidak independen dalam memutuskan kredit.

5) Kelemahan dalam melakukan pembinaan dan monitoring kredit debitur.

b. Faktor Eksternal Bank

1). Unsur kesengajaan yang dilakukan nasabah

a) Nasabah sengaja untuk tidak melakukan pembayaran angsuran kepada bank, karena nasabah tidak memiliki kemauan dalam memenuhi kewajibannya.

b) Debitur melakukan ekspansi terlalu besar, sehingga dana yang dibutuhkan terlalu besar. Hal ini akan memiliki dampak terhadap keuangan perusahaan dalam memenuhi kebutuhan modal kerja.

c) Penyelewengan yang dilakukan nasabah dengan menggunakan dana kredit tersebut tidak sesuai dengan tujuan penggunaan.

2). Unsur Ketidaksengajaan

a) Debitur mau melaksanakan kewajiban sesuai perjanjian, akan tetapi kemampuan perusahaan sangat terbatas, sehingga tidak dapat membayar angsuran.

b) Perusahaannya tidak dapat bersaing dengan pasar, sehingga volume penjualan menurun dan perusahaan rugi.

\footnotetext{
${ }^{6}$ Ibrahim, A., dan A. Rahmati. 2017. Analisis solutif Penyelesaian Pembiayaan Bermasalah di Bank syariah: Kajian pada produk Murabahah di bank Muamalat Indonesia Banda Aceh
} 
c) Perubahaan kebijakan dan peraturan pemerintah yang berdampak pada usaha debitur.

d) Bencana alam yang dapat menyebabkan kerugian debitur ${ }^{7}$.

\section{Penggolongan Kolektabilitas Pembiayaan}

Dalam Buku Ismail menjelaskan, Bank melakukan penggolongan kredit menjadi dua golongan yaitu kredit performing dan non-performing. Kredit performing disebut juga dengan kredit yang tidak bermasalah dibedakan menjadi dua kategori:

a. Kredit dengan kualitas lancar, yaitu kredit yang diberikan kepada nasabah dan tidak terjadi tunggakan, baik tunggakan pokok dan bunga. Debitur melakukan pembayaran angsuran tepat waktu sesuai dengan perjanjian kredit.

b. Kredit dalam kualitas dalam perhatian khusus, yaitu kredit yang masih digolongankan lancar, akan tetapi mulai terdapat tunggakan. Ditinjau dari segi kemampuan membayar, yang tergolong dalam kredit dalam perhatian khusus apabila terdapat tunggakan angsuran pokok atau bunga sampai dengan 90 hari.

Kredit non-performing merupakan kredit yang sudah dikategorikan kredit bermasalah, karena sudah terdapat tunggakan. Kredit non-performing disebut juga kredit bermasalah, dikategorikan menjadi tiga yaitu:

\section{a. Kredit kurang lancar}

1) Pengembalian pokok pinjaman dan bunganya telah mengalami penundaan pembayarannya melampaui 90 hari sampai dengan kurang dari 180 hari.

2) Pada kondisi ini hubungan debitur dengan bank memburuk.

3) Informasi keuangan debitur tidak dapat diyakini oleh bank.

\section{b. Kredit diragukan}

1) Penundaan pembayaran pokok atau bunga antara 180 hingga 270 hari.

2) Pada kondisi ini hubungan debitur dengan bank semakin memburuk.

3) Informasi keuangan sudah tidak dapat dipercaya.

c. Kredit Macet

merupakan kredit yang menunggak melampaui 270 hari atau lebih. Bank akan mengalami kerugian atas kredit macet tersebut ${ }^{8}$.

\section{Manajemen Risiko Lembaga Keuangan}

\footnotetext{
${ }^{7}$ Ismail. 2010. Manajemen Perbankan: Dari Teori Menuju Aplikasi. h.124

${ }^{8}$ Ismail. 2010. Manajemen Perbankan: Dari Teori Menuju Aplikasi. h.122
} 
Elmiliyani Wahyuni, Sri Maulidia : Analisis Penanganan Pembiayaan...

Adalah serangkaian metodologi dan prosedur yang digunakan untuk mengidentifikasi, mengukur, memantau dan mengendalikan risiko yang timbul dari seluruh kegiatan usaha bank.Secara umum risiko yang dihadapi lembaga keuangan perbankan syariah dan BMT bisa diklasifikasi menjadi dua bagian besar, yakni risiko yang sama dengan yang dihadapi bank konvensional dan risiko yang memiliki keunikan tersendiri karena harus mengikut prinsip-prinsip syariah. Risiko kredit, risiko pasar, risiko benchmark, risiko operasional, risiko likuiditas, dan risiko hukum, harus dihadapi bank syaariah. Tetapi karena harus mematuhi aturan syariah, risiko-risiko yang dihadapi bank syariah pun menjadi berbeda.

Bank syariah juga harus menghadapi risiko-risiko lain yang unik (khas). Risiko unik ini muncul karena isi neraca bank syriah yang berbeda dengan bank konvensional. Dalam hal ini pola bagi hasil (profit and sharing) yang dilakukan bank syariah menambah kemungkinan munculnya risiko-risiko lain. Seperti resiko likuiditas, resiko pasar, resiko kredit, resiko operasional, resiko kepatuhan, resiko hukum, resiko strategi, with drawal risk, fiduciary risk dan displaced commercial risk.

\section{Cara Penanganan Pembiayaan Bermasalah}

Dalam penyaluran pembiayaan apapun analisis dalam menganalisis permohonan pembiayaan, kemungkinan pembiayaan bermasalah pasti ada, hal ini kurang lebih disebabkan oleh dua 2 unsur, yakni dari pihak bank kurang teliti dalam menganalisa, atau bahkan dapat pula terjadi kecurangan yang terjadi di antara pihak analisis pembiayaan dengan pihak debitur sehingga analisanya dilakukan secara subyektif. Kemudian unsur yang kedua yaitu kelalaian dari pihak nasabah yang menyebabkan pembiayaan bermasalah, yang mana dapat disebabkan oleh faktor kesengajaan ataupun ketidaksengajaan

Restrukturisasi pembiayaan wajib didukung dengan analisis dan bukti-bukti yang memadai serta didokumentasikan dengan baik. Disamping dua kriteria tersebut maka bank syariah akan melakukan penyelamatan pembiayaan bermasalah dengan upaya restrukturisasi apabila nasabah masih mempunyai itikad baik dalam arti masih mau diajak kerjasama dalam upaya penyelamatan pembiayaan bermasalah, akan tetapi jika nasabah sudah tidak beritikad baik dalam arti tidak dapat diajak kerjasama dalam upaya penyelamatan pembiayaan bermasalah maka bank syariah akan melakukan upaya penyelesaian pembiayaan bermasalah.

a. Penyelesaian melalui Eksekusi Jaminan 
Elmiliyani Wahyuni, Sri Maulidia : AnalisisPenangananPembiayaan...

Penyelesaian melalui eksekusi jaminan dilakukan oleh bank syariah bilamana berdasarkan evaluasi ulang pembiayaan, propek usaha tidak ada, dan atau nasabah tidak kooperatif untuk menyelesaikan pembiayaan atau upaya penyelamatan dengan upaya restrukturisasi tidak membawa hasil melancarkan kembali pemiayaan tersebut. Maka upaya penyelsaiannya pembiayaan bermasalah dengan cara eksekusi jaminan.

b. Penyelesaian lewat Badan Arbitrase Syariah Nasional

Berdasarkan klausula dalam perjanjian pembiayaan, bilamana jika salah satu pihak tidak menunaikan kewajibannya atau terjadi perselisihan diantara kedua belah pihak dan tidak tercapai kesepakatan melalui musyawarah, maka penyelsaianya melalui Badan Arbitrase Nasional (BASYARNAS) berwenang:

1) Menyelesaikan secara adil dan cepat sengketa muamalah yang timbul dalam bidang perdagangan, keuangan industri, yang menurut hukum dan peraturan perundangundangan dikuasai sepenuhnya oleh pihak yang bersengketa, dan para pihak sepakat secara tertulis untuk menyerahkan penyelsaiannya kepada BASYARNAS sesuai dengan prosedur BASYARNAS.

2) Memberikan pernyataan yang mengikat atas permintaan para pihak tanpa adanya suatu sangketa mengenai persoalan berkenaan dengan suatu perjanjian

c. Penyelesaian dengan litigasi

Penyelsaian lewat litigasi akan ditempuh oleh bank bila nasabah tidak beritikad baik yaitu tidak menunjukkan kemauan untuk memenuhi kewajibannya sedangkan nasabah sebenarnya masih mempunyai harta kekayaan lain yang tidak dikuasai oleh bank atau sengaja disembunyikan untuk menyelesaikan kredit macetnya.

Sejak di undangkanya undang-undang nomor 3 tahun 2006 tentang peradilan agama maka bilamana terjadi sengketa dalam bidang muamalah maka diselesaikan lewat pengadilan agama. Tujuan dari keberadaan peradilan agama adalah bertugas dan berwenang memeriksa, memutus dan menyelesaikan perkara di tingkat pertama antara orang-orang yang beragama Islam di bidang perkawinan, warisan, wasiat, hibah, waqaf, zakat, infaq, dan ekonomi syariah

d. Hapus buku dan hapus tagih

Hapus buku adalah tindakan administratif bank untuk menghapus buku pembiayaan yang memiliki kualitas macet dari neraca sebesar kewajiban nasabah 
Elmiliyani Wahyuni, Sri Maulidia : Analisis Penanganan Pembiayaan...

tanpa menghapus hak tagih bank kepada nasabah. Hapus tagih adalah tindakan bank menghapus kewajiban nasabah yang tidak dapat diselesaikan, dalam arti kewajiban nasabah dihapuskan tidak tertagih kembali. Hapus buku dan hapus tagih hanya dapat dilakukan terhadap pembiayaan yang memilki kualitas macet. Hapus buku tidak dapat dilakukan terhadap sebagian pembiayaan, sedangkan hapus tagih dapat dilakukan baik untuk sebagian atau seluruh pembiayaan.

Hapus tagih terhadap sebagian pembiayaan hanya dapat dilakukan dalam rangka restrukturasi pembiayaan atau dalam rangka penyelsaian pembiayaan. Hapus buku atau hapus tagih hanya dapat dilakukan setelah bank syariah melakukan berbagai upaya untuk memperoleh kembali aktiva produktif yang diberikan .

\section{Resiko dalam Pembiayaan Murabahah}

Pembiayaan berdasarkan pembagian resiko yang diidentikan dengan model teoritis perbankan Islam tidak tampak menjadi karakter utama praktek murabahah bank-bank Islam. Namun demikian, para pendukung bank syariah mengatakan bahwa dalam murabahah, faktor pembagian resiko tetap ada, yang membei barang. Berikut resiko yang terkait dalam murabahah sebagai berikut:

a. Resiko yang terkait dengan barang

Bank syariah membeli barang yang diminta oleh nasabah murabahah-nya dan secara teoritis menanggung resiko kehilangan atau kerusakan pada barang-barang tersebut dari saat pembelian sampai diserahkan kepada nasabah. Dalam kontrak murabahah, bank syariah diwajibkan untuk menyerahkan barang kepada nasabah dalam kondisi yang baik. Bahkan, nasabah berhak menolak barang-barang yang sudah rusak, yang kurang jumlahnya atau tidak sesuai dengan spesifikasinya. Bank syariah bagaimanapun juga dalam prakteknya menghindari resiko-resiko tersebut dengan asuransi dan klausul kontrak, yang telah disusun sedemikian rupa sehingga membantu bank syariah untuk menghindari resiko yang terkait dengan barang. Dengan demikian, segala resiko yang terkait dengan barang, yang secara teoritis harus ditanggung bank, secara efektif telaah terhindarkan.

b. Resiko yang terkait dengan nasabah

Janji nasabah murabahah untuk membeli barang yang dipesan dalam suatu transaksi murabahah, tidaklah mengikat. Oleh sebab itu, nasabah berhak menolak untuk membeli barang ketika bank syariah menawari mereka dalam penjualan. 
Elmiliyani Wahyuni, Sri Maulidia : AnalisisPenangananPembiayaan...

Dalam prakteknya, resiko terahadap kemungkinan penolakan nasabah untuk membeli barang dapat dihindari dengan pembayaran di muka (sepertiga dari total harga, misalnya), dengan jaminan, jaminan pihak ketiga, dan dengan klausul kontrak. Dengan demikian, semua resiko yang secara teoritis mungkin ada dalam kaitannya dengan penolakan nasabah untuk membeli barang, sebenarnya telah hilang dalam praktek perbankan syariah.

c. Resiko yang terkait dengan pembayaran

Resiko tidak terbayar penuh atau sebaian dari uang muka, seperti yang dijadwalkan dalam kontrak, memang ada dalam pembiayaan murabahah. Bank syariah menghindari resiko ini dengan adanya janji tertulis, jaminan, jaminan pihak ketiga dan klausul kontrak yang menyatakan bahwa semua hasil dari barang-barang murabahah yang dijual kepada pihak ketiga dengan tunai maupun kredit harus ditaruh dibank sampai apa yang menjadi hak bank dibayar kembali sepenuhnya. Jika tidak adanya pembayaran ini disebabkan oleh faktor di luar kemampuan nasabah, bank syariah secara moral berkewajiban menjadwal ulang waktu, tetapi jika ia tidak melakukannya, maka bank syariah telah mengadopsi konsep denda untuk dijatuhkan kepada nasabah. Dengan demikian, dalam praktek, bank syriah secara efektif telah menghilangkan semua resiko dalam pelaksanaan murabahah $^{9}$.

\section{METODE PENELITIAN}

Metode penelitian yang penulis lakukan adalah penelitian lapangan (field research), dengan pendekatan kualitatif. Disini penulis langsung melakukan penggalian data kepada pihak-pihak yang berkepentingan di KJKS BMT Al-Makmur Cubadak Lima Kaum yaitu pimpinan, manager dan marketingBMT yang berhubungan dengan Pembiaayaan murabahah pada KJKS BMT Al-Makmur Cubadak Lima Kaum, Kabupaten Tanah Datar

Adapun sumber data yang penulis gunakan dalam penelitian ini adalah melalui tanya jawab lisan antara pewawancara dengan responden secara langsung dari praktisi BMT selaku narasumber Suhatri Mariko (pimpinan), Sawirman (manager) dan januarif (marketing ) KJKS BMT Al-Makmur Cubadak Lima Kaum. Sedangkan data sekunder diperoleh dari laporan keuangan mengenai pembiayaan bermasalah KJKS BMT AlMakmur Cubadak Lima Kaum Tahun 2014-2018.

\footnotetext{
${ }^{9}$ Rahmawaty, A. 2007. Ekonomi Syariah Tinjuan Kritis Produk Murabahah dalam Perbankan Syariah di Indonesia. h. 196
} 
Elmiliyani Wahyuni, Sri Maulidia : Analisis Penanganan Pembiayaan...

Instrumen pada penelitian ini adalah penulis sendiri yang berperan sebagai instrumen utama dalam menjaring data dan informasi yang diperlukan. Teknik analisis data pada penelitian ini adalah melalui wawancara, penulis melakukan wawancara secara mendalam kepada pimpinan, manager, dan markrting BMT yang berhubungan dengan pembiayaan diKJKS BMT Al-Makmur Cubadak Lima Kaum.

\section{HASIL ANALISIS DAN PEMBAHASAN}

1. Penyebab terjadinya pembiayaan murabahah non performing financing (NPF) berdasarkan Mitigation of Risk pada KJKS BMT Al-Makmur Cubadak Lima Kaum

Semakin tinggi tingkat risiko pembiayaan yang dihadapi BMT membutuhkan pengelolaan risiko yang tepat dan lebih baik untuk meminimalisir risiko pembiayaan. Berdasarkan hasil penelitian yang penulis lakukan dengan pimpinan, manager dan marketing pembiayaan murabahah KJKS BMT Al-Makmur Cubadak Lima Kaum yang menjadi penyebabterjadinya pembiayaanmurabahahadalah:

a. Faktor internal

1) Analisis kurang tepat dalam menganalisa karakter nasabah

Karakter merupakan penilaian terhadap calon nasabah pembiayaan yang dilakukan untuk melihat watak dari orang-orang yang akan diberikan pembiayaan benar-benar dapat dipercaya, hal ini tercermin dari latar belakang pekerjaan maupun yang bersifat pribadi serta cara hidup dan gaya hidup yang dijalaninya dan lingkungan sosial hal tersebut perlu diketahui agar tidak menyulitkan dikemudian hari. Sedangkan mitigasi of risk itu menghindari risiko atau kerugian atas pembiayaan yang diberikan kepada nasabah.

Berdasarkan hasil wawancara dengan pimpinan KJKS BMT Al-Makmur Cubadak Lima Kaum menjelaskan bahwa dari pihak BMT sendiri sebelum memberikan pembiayaan kepada calon nasabahkurang dalam menganalisa karakter nasabah dikarenakan pihak BMT terlalu fokus dalam mensosialisaikan produk dan pembiayaan yang ada di KJKS BMT Al-Makmur Cubadak Lima Kaum, sehingga pihak BMT kurang mendalam dalam menilai aspek kepribadian nasabah. Dan setelah berjalannya pembiayaan yang diberikan kepada nasabah pihak BMT melihat bahwa karakter nasabah yang diberikan pembiayaan tidak beritikad baik dalam memenuhi kewajibannya (Suhatri Mariko, wawancara, tanggal 27/08/2019, Jam, 10.30-12.00 WIB). Begitu juga yang disampaikan oleh manager BMT bahwa 
Elmiliyani Wahyuni, Sri Maulidia : AnalisisPenangananPembiayaan...

analisa karakter nasabah masih belum maksimal kami lakukan terhadap calon nasabah yang akan diberikan pembiayaan ${ }^{10}$

Menurut analisa penulismitigasi risiko yang harus dilakukan oleh pihak BMT dalam menghindari risiko yang akan terjadi yaitu melihat karakter calon nasabah sebelum memberikan pembiayaan terlebih dahulu pihak KJKS BMT AlMakmur Cubadak Lima Kaum menilai dan menggali informasi tentang calon nasabah melalui pihak-pihak lain yang mengenal dengan baik calon nasabah, misalnya mencari informasi tentang karakter calon nasabah melalui tetangga, teman kerja, atau rekan usaha calon nasabah. Informasi dari pihak lain tentang calon nasabah akan lebih meyakini bagi KJKS BMT Al-Makmur Cubadak Lima Kaum dalam mengetahui karakter nasabah.

2) Kelemahan dalam melakukan pembinaan dan monitoring pembiayaan Monitoring merupakan kunci utama dalam pengelolaan pembiayaan yang disalurkan baik pembiayaan muabahah, ijarah yang diberikan termasuk juga kepada pengawasan dan pembinaan.Berdasarkan hasil wawancara pelaksanaan pembinaan dan monitoring pembiayaan yang dilakukan oleh KJKS BMT Al-Makmur Cubadak Lima Kaum dengan melakukan pemantauan langsung serta melihat perkembangan usaha nasabah (Suhatri Mariko, wawancara, tanggal 21/08/2019, Jam, 10.30-12.00 WIB)

Menurut penulis strategi monitoring yang dilakukan belum maksimal karena hanya melakukan pemantauan secara langsung terhadap perkembangan usaha nasabah, jika monitoring dilakukan dengan menganalisis pembayaran angsuran nasabah,menilai kondisi keuangan dan pemantauan secara dini terhadap kolektabilitas serta menjaga komunikasi yang baik dengan nasabah, menurut analisa penulis jika hal tersebut dapat dilakukan oleh KJKS BMT Al-Makmur Cubadak Lima Kaum maka akan mengurangi pembiayaan bermasalah dari tahun ke tahun.

b. Faktor Eksternal

1) Penurunan pendapatan usaha nasabah

Berdasarkan hasil wawancara dengan marketing KJKS BMT Al-Makmur Cubadak Lima Kaum terjadinya penurunan pendapatan nasabah disebabkan kurang

\footnotetext{
${ }^{10}$ Sawirman. Wawancara dengan Manager KJKS BMT Al-Makmur Cubadak Lima Kaum. Wawancara tanggal 27/08/2019, Jam, 10.30-12.00 WIB
} 
Elmiliyani Wahyuni, Sri Maulidia : Analisis Penanganan Pembiayaan...

berkembangnya usaha yang dijalankan. Hal ini disebabkan oleh berbagai faktor diantaranya kurangnya promosi terhadap produk yang nasabah jual, kurangnya kecakapan dalam mengelola usaha, perekonomian yang tidak selalu stabil, sehingga yang dari awal nasabah mampu untuk membayar angsuran pembiayaan dengan adanya penurunan nilai dari usaha nasabah, maka tidak sanggup lagi untuk menyicil angsuran dengan beralasan angsuran terlalu besar (Januarif, wawancara, tanggal 30/08/2019, Jam, 10.00-11.00 WIB)

Menurut penulis hal tersebut dapat berpengaruh terhadap pendapatan yang diterima oleh pihak BMTdikarenakan nasabah tidak mampu membayarkan angsuranya dan terjadinya penunggakan yang berkelanjutan, apabila dalam melakukan analisa calon nasabah BMT mampu menilai prospec usaha calon nasabah dimasa yang akan datang apakah menguntungkan atau tidak. Hal ini penting mangingat jika suatu fasilitas pembiayaan yang dibiayai tanpa mempunyai prospec bukan hanya BMT yang mengalami kerugian tetapi juga nasabah.

2) Nasabah pembiayaan sengaja menghindar dari pihak BMT dalam pembayaran angsuran

Dalam temuan penelitian wawancara dengan januarif selaku marketing adanya itikad yang tidak baik terindikasi dari seringnya terjadi penundaan pembayaran, walaupun secara pengamatan nasabah mampu untuk membayar. Fakta yang sering terjadi adalah keuntungan yang didapat nasabah dari usaha seharusnya disisihkan untuk pembayaran angsuran, tetapi digunakan untuk keperluan lain(Januarif, wawancara, tanggal 30/08/2019, Jam, 10.00-11.00 WIB)

Menurut analisa penulis sebelum memberikan pembiayaan marketingharus melakukan analisa karakter calon nasabah yang ada ditengah masyarakat secara mendalam di lihat dari segi kepribadian atau tingkah sehari-hari maupun masa lalunya, dan juga melihat dari sikap, emosi, tingkah laku dan tindakan nasabah dalam menghadapi suatu masalah. Apabila pihak KJKS BMT Al-Makmur Cubadak Lima Kaum lebih selektif dalam hal memilih karakter calon nasabah yang baik maka tentunya risiko pembiayaan dapat terhindarkan. 
Elmiliyani Wahyuni, Sri Maulidia : AnalisisPenangananPembiayaan...

\section{Prosedurdan sistem kerja KJKS BMT Al-Makmur Cubadak Lima Kaum dalam menangani pembiayaan murabahah non performing financing dengan mitigation of risk.}

Semua risiko menjadi prioritas, namun yang lebih diutamakan dari risiko lainnya adalah risiko pembiayaan / kredit, risiko strategik dan risiko kepatuhan. Ketiga risiko ini bersumber dari dua pihak yakni pihak BMT dan nasabah sendiri, sehingga butuh usaha maksimal untuk meminimalisir dampak dari risiko yang akan muncul. KJKS BMT Al-Makmur Cubadak Lima Kaum memilih solusi mitigasi of risk dengan menghindari serta mengurangi risiko yang akan muncul.

\section{a. Berdasarkan fatwa Dewan Syariah Nasional}

1) Fatwa DSN Nomor 17/DSN-MUI/IX/2000 tentang sanksi atas nasabah mampu yang menunda-nunda pembayaran

Dalam fatwa ini menjelaskan bahwa nasabah yang mampu membayar angsuranya tetapi menunda-nunda pembayaran dengan sengaja maka akan dikenakan sanksi oleh pihak yang memberikan pembiayaan. Berdasarkan fatwa tersebut KJKS BMT Al-Makmur Cubadak Lima Kaum juga menerapkan sanksi kepada nasabah yang memang sengaja menunda pembayaran angsuran dengan diberlakukannya denda sebesar Rp 1000 untuk satu kali keterlambatan, dan sanksi tersebut berlaku terhadap pembiayaan baik itu besar maupun kecil, sanksi ini diberlakukan apabila nasabah terlambat mengembalikan angsurannya dalam jatuh tempo yang telah dientukan. Sedangkan bagi nasabah yang benar-benar tidak sanggup untuk mengembalikan angsurannya dalam waktu jatuh tempo tidak dikenakan sanksi, karena mempertimbangkan kondisi nasabah yang dilihat dari aspek kemalangan yang menimpa nasabah, kondisi keuangan serta usaha yang menurun. ${ }^{11}$ (Sawirman, wawancara, tanggal 28/08/2019, Jam, 10.00-11.00 WIB).

Menurut penulis dalam hal ini pihak KJKS BMT Al-Makmur Cubadak Lima Kaum sudah sesuai dengan ketentuan fatwa, tetapi alangkah baiknya jika denda yang diterapkan dibedakan berdasarkan jumlah pembiayaan yang diberikan agar nantinya tidak menimbulkan permasalahan yang berkemungkinan nasabah yang pembiayaannya lebih besar sengaja melalaikan kewajibannya dalam mengembalikan angsuran. Hal ini tentu akan menjadi permasalahan dikemudian

${ }^{11}$ Sawirman. Wawancara dengan Manager KJKS BMT Al-Makmur Cubadak Lima Kaum. Wawancara tanggal 28/08/2019, Jam, 10.00-11.00 WIB 
Elmiliyani Wahyuni, Sri Maulidia : Analisis Penanganan Pembiayaan...

hari, maka dari itu pihak KJKS BMT Al-Makmur Cubadak Lima Kaum lebih menekankan sanksi terhadap pembiayaan yang disalurkan kepada nasabah, agar nantinya mampu meminimalisir kemungkinan terjadinya penunggakan pengembalian pembiayaan oleh nasabah.

2) Fatwa DSN Nomor 46/DSN-MUI/II/2005 tentang potongan tagihan murabahah Lembaga keungan syariah dapat memberikan potongan dari total kewajiban pembayaran kepada nasabah dalam transaksi murabahah yang telah melakukan kewajiban pembayaran cicilan dengan tepat waktu. Pihak KJKS BMT Al-Makmur Cubadak Lima Kaum juga menerapkan potongan tagihan kepada nasabah yang mampu menyelesaikan pelunasan pembiayaan dengan cepat sebelum masa jatuh tempo habis dengan memberikan bonus sebesar 20\% dari margin 11. Menurut penulis dalam kebijakan ini pihak BMT telah mampu memberikan motivasi tidak langsung kepada nasabah, dan juga dapat mengurangi tingkat risiko pembiayaan bermasalah dikemudian hari.

3) Fatwa DSN Nomor 48/DSN-MUI/II/2005 tentang penjadwalan kembali Lembaga keuangan syariah boleh melakukan penjadwalan kembali (rescheduling) terhadap tagihan murabahah bagi nasabah yang tidak bisa menyelesaikan pembiayaanya sesuai dengan jumlah dan waktu yang telah disepakati dengan tidak menambah jumlah tagihan yang tersisa dan perpanjangan masa pembayaran harus berdasarkan kesepakatan kedua belah pihak.

Sedangkan proses yang dilakukan oleh KJKS BMT Al-Makmur Cubadak Lima Kaum telah melakukan penjadwalan kembali terhadap nasabah yang masih mempunyai keinginan untuk membayar angsuranya, dengan dijadwalkan kembali berdasarkan rentang waktu yang diberikan tergantung kesepakatan atau kemampuan membayar oleh nasabah berdasarkan sisa hutang. terkecuali bagi nasabah yang tidak ada keinginan untuk membayar kewajibannya tetap dilakukan penagihan sampai anggota nasabah tersebut dapat membayar kembali ${ }^{11}$.

Contoh kepada nasabah buk weni yang mengajukan pembiayaan untuk usaha kedai harian sebesar Rp 3000.000, kemudian pihak BMT memberikan dengan jaminan berupa BPKB, dengan margin 16\% dan jangka waktu selama 12 bulan kepada buk weni. Angsuran yang harus dibayar yaitu angsuran pokok Rp. 250.000 ditambah margin/keuntungan Rp. 480.000. jadi jumlah angsuran per bulan yang harus dibayar yaitu Rp. 730.000. perhitungannya sebagai berikut: 
Elmiliyani Wahyuni, Sri Maulidia : AnalisisPenangananPembiayaan...

\author{
Jumlah pembiayaan $=$ Rp. 3000.000 \\ Jangka waktu 12 bulan
}

Dengan hasil Rp. 250.000

Bagi hasil Rp. 3000.000 x16\% = Rp. 480.000. karena buk weni dalam mengangsur pembiayaan tidak sesuai perhitungan yang telah ditentukan dan pada saat jatuh tempo pada bulan ke 7 buk weni belum mampu melunasi jumlah utangnya, buk weni masih mempunyai sisa tagihan senilai $\mathrm{Rp}$ 1.500.000. dan kemudian dijadwalkan kembali dengan jangka waktu 12 bulan. Dengan perhitungan setelah rescheduling

\title{
Sisa kewajiban pokok $=\operatorname{Rp} 1.500 .000$

Jangka waktu 12 bulan

Dengan hasil Rp. 125.000

Dan bagi hasilnya Rp. $1.500 .000 \times 16 \%=$ Rp. 240.000. jadi angsuran yang harus dibayarkan buk weni per bulannya adalah Rp. 365.000. dari paparan diatas jumlah tagihan yang harus dibayar buk weni jika tidak mengalami pembiayaan bermasalah yaitu biaya pokok ditambah dengan margin jumlahnya Rp. 8 760.000. dan tagihan yang dibayarkan buk weni setelah rescheduling adalah Rp. 4.380.000 setelah dikalikan dengan jangka waktu 12 bulan. Total pembiayaan yang diangsur buk weni sebelum rescheduling Rp. 1.500 .000 ditambah setelah rescheduling menjadi Rp. 5.880.000. Rescheduling yang diberikan kepada buk weni tidak ada kelebihan, tetapi jumlah keuntungannya malah berkurang.

Menurut analisa penulis BMT telah melakukan sesuai dengan ketentuan yang ada, dalam hal ini BMT mampu meminimalisir terhadap tunggakan nasabah yang nantinya akan menjadi pembiayaan bermasalah, dan apabila pihak BMT lebih giat dalam melakukan pengawasan serta memberikan pembinaan terhadap nasabah pembiayaan maka kedepannya BMT akan lebih memahami serta mempertimbangkan sebelum memberikan pembiayaan kepada nasabah dalam hal ini pihak BMT bisa mengantisipasi resiko yang akan terjadi terhadap pembiayaan.

4) Fatwa DSN Nomor 49/DSN-MUI/II/2005 tentang konversi akad Berdasarkan fatwa ini dalam melakukan konversi akad dengan caraobjek atau agunan murabahah dijual oleh nasabah kepada LKS dengan harga pasar, nasabah melunasi sisa hutangnya kepada LKS dari hasil penjualan, apabila hasil penjualan 
Elmiliyani Wahyuni, Sri Maulidia : Analisis Penanganan Pembiayaan...

melebihi sisa hutang maka kelebihan itu dapat dijadikan uang muka untuk akad ijarah atau bagian modal dari mudharabah dan musyarakah.

Berdasarkan hasil wawancara dengan manager KJKS BMT Al-Makmur Cubadak Lima Kaum menjelaskan bahwa pada BMT tidak menerapkan konversi akad tersebut dikarenakan semenjak timbulnya pembiayaan bermasalah tidak pernah melakukan penarikan jaminan di karenakan barang jaminan tersebut hilang atau rusak pada nasabah dan juga akad pembiayaan yang berjalan di BMT hanya berupa akad murabahah.Jadi dalam menyelesaikan pembiayaan bermasalah tanpa melalui konversi akad pihak BMT hanya melakukan penagihan secara berkelanjutan serta melakukan pembinaan kepada11. Dalam hal ini menurut penulis jika nasabah benarbenar tidak mampu membayar kembali angsuranya sementara sudah diberi toleransi tambahan waktu, dan margin juga sudah diperkecil, tetapi masih juga tidak mampu untuk membayar, maka sebaiknya akad yang sedang dipergunakan dalam pembiayaan tersebut dikonversi menjadi akad qardhul hasan karena dengan menggunakan akad ini nasabah pembiayaan macet cukup membayar pokonya saja dari pembiayaan yang diberikan. Karena pembiayaan akad qardhul hasan merupakan akad yang mengandung nilai orientasi sosial atau falah oriented.

5) Fatwa DSN Nomor 47/DSN-MUI/II/2005 tentang penyelesaian piutang murabahah bagi nasabah yang tidak mampu membayar

Fatwa ini menjelaskan objek murabahah atau jaminan lainnya dijual nasabah melalui lembaga keuangan syariah dengan harga pasar yang disepakati, namun agunan yang dijadikan nasabah dalam melakukan pembiayaan, tidak dapat dijual oleh pihak KJKS BMT Al-Makmur Cubadak Lima Kaum karena agunan yang dijadikan jaminan berupa barang elektronik hilang dan rusak oleh nasabah sehingga tidak ada lagi nilai jual beli terhadap barang tersebut (Suhatri Mariko, wawancara, tanggal 27/08/2019, Jam, 10.00-12.00 WIB).

Menurut analisa penulis kurang nya prinsip kehati-hatian dan tanggung jawab oleh nasabah untuk menjaga barang jaminan, atau pihak BMT bisa mengambil kebijakkan bahwa barang jaminan berada dalam pemeliharaan BMT.jadi jika nasabahpembiayaan bermasalah tidak mampu melunasi sisa angsurannya maka jaminan tersebut bisa dijual. 
Elmiliyani Wahyuni, Sri Maulidia : AnalisisPenangananPembiayaan...

\section{b. Berdasarkan Surat Edaran Bank Indonesia}

Berdasarkan surat edaran bank Indonesia (SEBI) N0.13/18/DPbs tanggal 30 mei 2011 tentang perubahan SEBI nomor 10/34/DPbs tanggal 22 oktober 2008 tentang restrukturisasi pembiayaan bagi Bank Umum Syariah dan Unit Usaha Syariah dalam restrukturisasi pembiayaan wajib didukung dengan analisa dan bukti-bukti yang memadai serta didokumentasikan dengan baik. Disamping dua kriteria tersebut BMT akan melakukan penyelamatan pembiayaan bermasalah dengan upaya restrukturisasi apabila nasabah masih mempunyai itikad baik dalam arti masih mau diajak kerjasama dalam upaya penyelamatan pembiayaan bermasalah, akan tetapi jika nasabah sudah tidak beritikad baik dalam arti tidak dapat diajak kerjasama dalam upaya penyelamatan pembiayaan bermasalah maka lembaga keuangan syariah akan melakukan uapaya penyelesaian pembiayaan bermasalah sebagai berikut:

1) Penyelesaian melalui eksekusi jaminan

Penyelesaian melalui eksekusi jaminan dilakukan oleh BMT bilamana telah melakukan evaluasi ulang pembiayaan, prospek usaha yang tidak ada, dan nasabah tidak kooperatif untuk menyelesaikan pembiayaan atau penyelamatan dengan upaya restrukturisasi tidak membawa hasil melancarkan kembali pembiayaan tersebut, maka upaya penyelesaian pembiayaan bermasalah dengan cara eksekusi jaminan.

Namun proses yang dilakukan oleh KJKS BMT Al-Makmur Cubadak Lima Kaum tidak melakukan eksekusi jaminan terhadap nasabah yang mengalami pembiayaan macet, disebabkan karena jaminan yang berupa barang elektronik rumah tangga yang dijadikan sebagai jaminan pembiayaan oleh nasabah hilang atau rusak sehingga nilai jual barang jaminan tersebut tidak ada lagi, maka dalam hal ini pihak BMT hanya mampu melakukan pembinaan kepada nasabah agar barang jaminan bisa dikembalikan lagi sesuai dengan kad pembiayaan yang telah disepakati (Sawirman, wawancara, tanggal 28/08/2019, Jam, 10.00-12.00 WIB).

2) Penyelesaian melalui Badan Arbitrase Syariah Nasional (BASYARNAS)

Berdasarkan klausula dalam perjanjian pembiayaan, bilamana jika salah satu pihak tidak menunaikan kewajibannya atau terjadi perselisihan diantara kedua belah pihak dan tidak tercapai kesepakatan melalui musyawarah, maka penyelesaiannya 
Elmiliyani Wahyuni, Sri Maulidia : Analisis Penanganan Pembiayaan...

melalui Badan Arbitrase Nasional yang berwenang menyelesaikan secara adil dan cepat.

Namun yang di terapkan oleh KJKS BMT Al-Makmur Cubadak Lima Kaum dalam menghadapi nasabah yang tidak memenuhi kewajibannya dalam mengembalikan angsuran melalui surat peringatan, pembinaan dan juga penagihan kewajiban nasabah secara berkelanjutan dikarenakan berdasarkan wilayah berdirinya BMT tidak ada lembaga BASYARNAS (Sawirman, wawancara, tanggal 28/08/2019, Jam, 10.00-11.00 WIB)

Menurut penulis dalam mengatasi prilaku nasabah yang mengalami pembiayaan macet tanpa adanya lembaga BASYARNAS, tentunya pihak BMT akan mengalami kesulitan apabila dalam musyawarah tidak ditemui solusi terhadap permasalahan nasabah, maka dari pihak BMT sebelum memberikan pembiayaan harus disebutkan dalam akad, jika tidak mampu dalam membayar kembali angsuran nasabah pembiayaan yang macet, maka bisa dilanjutkan melalui jalur litigasi

3) Penyelesaian dengan litigasi

Penyelesaian lewat litigasi ini akan ditempuh oleh lembaga keuangan syariah apabila nasabah tidak beritikad baik dan tidak menunjukan kemauan untuk memenuhi kewajiban sedangkan nasabah sebenarnya masih mampuuntuk membayar angsuran pembiayaanya. Namun proses yang dilakukan oleh KJKS BMT Al-Makmur Cubadak Lima Kaum hanya dengan jalan musyawarah saja kepada nasabah (Sawirman, wawancara, tanggal 29/08/2019, Jam, 10.00-11.00 WIB.

Menurut analisa penulis musyawarah yang dilakukan kepada nasabah kurang efektif karena tidak dapat menyelesaikan pembiayaan macet secara cepat, apabila pihak BMT dapat melakukan tindakan yang lebih tegas terhadap nasabah yang sengaja dalam menunda pembayaran selain sanksi yang diberikan seharusnya proses hukum juga perlu diterapkan, agar pembiyaan bermasalah yang sedang terjadi dapat teratasi.

4) Hapus buku dan hapus tagih

Hapus buku merupakan tindakan administratif lembaga keuangan syariah untuk menghapus buku pembiayaan yang memiliki kualitas macet dari neraca sebesar kewajiban nasabah tanpa menghapus hak kepada nasabah. Sedangkan hapus tagih adalah tindakan lembaga keuangan syariah menghapus kewajiban nasbah yang 
tidak dapat diselesaikan, dalam arti kewajiban nasabah dihapuskan tidak tertagih kembali.

Tahap yang dilakukan KJKS BMT Al-Makmur Cubadak Lima Kaum hanya melakukan hapus buku dengan sumber dana yang diperoleh dari dana risiko, yang mana dana risiko berasal dari rapat anggota tahunan, misalnya dalam satu tersebut tahun terkumpul uang sebesar Rp 3.000.000 yang direalisasikan untuk menutupi sisa hutang atau kewajiban nasabah yang bermasalah sehingga dalam daftar pencatatan nominatif nasabah hilang atau telah dihapus karena sudah ditutupi dari dana risiko, sedangkan hapus tagih tetap diberlakukan oleh pihak BMT kepada nasabah yang mengalami pembiayaan macet dalam artian tagihan tetap (Sawirman, wawancara, tanggal 29/08/2019, Jam, 10.00-11.00 WIB). Menurut penulis dengan melakukan hapus buku terhadap nasabah pembiayaan macet dapat mengurangi jumlah pembiayaan bermasalah yang ada tetapi sebelum melakukan penghapusan buku terlebih dahulu pihak BMT melakukan pemberian surat peringatan hingga $3 \mathrm{x}$ ddan juga pembinaan kepada nasabah.

\section{E. KESIMPULAN}

Berdasarkan pembahasan dan merujuk pada hasil penelitian yang telah penulislakukan, maka dapat disimpukan beberapa hal sebagai berikut:

Pertama, risiko yang dihadapi BMT berkaitan dengan risiko pembiayaan/ kredit, risiko strategik dan risiko kepatuhan. Umunya risiko-risiko ini muncul karena permasalahan masih-masing pihak, risiko stategik dan kepatuhan muncul karena kesalahan pihak BMT yaitu terjadinya pembiayaan murabahah bermaslah disebabkan karena pihak BMT sendiri sebelum memberikan pembiayaan kepada calon nasabah kurang dalam menganalisa karakter nasabah, Kelemahan dalam melakukan pembinaan dan monitoring kepada nasabah setelah dilakukan pencairan pembiayaan. Sedangkan risiko pembiayaan muncul karena kesalahan dari pihak nasabah yaituterjadinya penurunan pendapatan usaha nasabah disebabkan kurangnya kecakapan dalam mengelola usaha, perekonomian yang tidak selalu stabil, dan nasabah pembiayaan sengaja menghindar dari pihak BMT dalam pembayaran angsuran.

Kedua, prosedur dan sistem kerja BMT dalam menangani pembiayaan murabahah non performing financing (NPF) dengan mitigation of riskialah menghindari dan mengurangi risko. Mitigasi menghindari risiko dilakukan dengan menerapkan 
Elmiliyani Wahyuni, Sri Maulidia : Analisis Penanganan Pembiayaan...

denda sebesar Rp 1000 untuk satu kali keterlambatan, dan memberikan potongan tagihan kepada nasabah yang mampu melunasi pembiayaan sebelum waktu jatuh tempo berakhir. Kemudian mitigasi kedua yang dilakukan mengurangi risiko dengan menerapkan pola pembiayaan untuk meringankan angsuran pembayaran anggota yang mengalami kesulitan dalam membayar, dengan sistem rescheduling,dalam hal ini BMT menerapkan pola perpanjangan waktu, dan kebijakan pengurangan tunggakan bagi hasil. Tetapi dalam hal lain BMT tidak melakukan penarikkan jaminan, konversi akad dan juga litigasi dikarenakan pihak BMT menyelesaiakan permasalahan pembiayaan dengan jalan musyawarah.

\section{DAFTAR PUSTAKA}

Antonio, Muhmmad Syafi'i. 2001. Bank Syariah: dari Teori dan Praktik. Gema Insani Press: Jakarta

Https://www.bi.go.id

Ibrahim, A., dan A. Rahmati. 2017. Analisis solutif Penyelesaian Pembiayaan Bermasalah di Bank syariah: Kajian pada produk Murabahah di bank Muamalat Indonesia Banda Aceh. Jurnal Kajian Ekonomi dan Bisnis Islam. 10 (1)

Ikatan Bankir Indonesia. 2014. Memahami Bisnis Bank Syariah. PT Gramedia Pustaka Utama: Jakarta

Ismail. 2010. Manajemen Perbankan: Dari Teori Menuju Aplikasi. Kencana : Jakarta .2013. Perbankan Syariah. Kencana: Jakarta

Ismail, Rifki dan farrel Muhammad Rizqi. 2016. Manajemen Risiko Bank Syariah. Bank Indonesia: Jakarta

Kolistiawan, B. 2014. Tinjauan Syariah Tentang Pembiayaan Bermasalah di Perbankan Syariah. Jurnal An-Nisbah. 1 (1)

Muhammad. 2005. Lembaga Ekonomi Syariah. Graha Ilmu: Yogyakarta

Putri, V.W. 2017. Pelaksanaan pengawasan pembiayaan yang sedang bermasalah (kredit macet) pada PT. Bank muamalat indonesia capem payakumbuh, Batusangkar: IAIN Batusangkar

Ilyas, R. 2015. Konsep Pembiayaan dalam Perbankan Syariah. Jurnal Penelitian. 9 (1)

Rahmawaty, A. 2007. Ekonomi Syariah Tinjuan Kritis Produk Murabahah dalam Perbankan Syariah di Indonesia. Jurnal Ekonomi Islam. 1 (2)

Ridwan, Muhammad. 2004. Manajemen Baitul Maal wa Tamwil (BMT). UII Press: Yogyakarta 
Elmiliyani Wahyuni, Sri Maulidia : AnalisisPenangananPembiayaan...

Sadrah, Engkos. 2004. BMT dan Bank Islam: Instrumen Lembaga Keuangan Syariah. Pustaka Bani Quraisy: Bandung

Sakti, A. 2013. Pemetaan Kondisi dan Potensi BMT kemitraan dalam rangka memperluas pasar dan jangkauan pelayanan bank syaraiah kepada usaha mikro.Jurnal Al-Muzara'ah. 1 (1)

Saleh, Muhammad. 2018. Jual Beli dalam Perspektif Ekonomi Islam. Gava Media: Yogyakarta

Sinungan, Muchdarsyah. 2000. Manajemen Dana Bank. PT Bumi Aksara: Jakarta

Soemitra, Andri. 2010. Bank dan Lembaga Keungan Syariah. Kencana: Jakarta

Sudarsono, Heri. 2003. Bank dan Lembaga Keuangan Syariah deskripsi dan ilustrasi. Ekonisia: Yogyakarta

Sugiyono. 2010. Metode Penelitian Pendidikan pendekatan Kuantitatif Kualitatif dan $R \& D$. Anggota Ikatan Penerbit Indonesia (IKAPI): Bandung

.2012. Memahami Penelitian Kualitatif. Alfabeta: Bandung

.2013. Metode Penelitian Kuantitatif Kualitatif dan R\&D. Anggota Ikatan Penerbit Indonesia (IKAPI): Bandung

.2016. Memahami Penelitian Kualitatif. Anggota Ikatan Penerbit Indonesia (IKAPI): Bandung

Sutedi, Adrian. 2011. PerbankanSyariah. Ghalia Indonesia: Jakarta

Tim Pengembangan Perbankan Syariah Institut Bankir Indonesia. 2003. Konsep Produk dan Implementasi operasional Bank Syariah. Djambatan: Jakarta

Wawancara dengan Manager KJKS BMT Al-Makmur Cubadak Lima Kaum (Sawirman)

Yunus, jamal Lulail. 2009. Manajemen Bank Syariah. UIN Malang Press: Malang 